\title{
Cold and Efficient Killing Machines ${ }^{1}$
}

\author{
Jacob Rogozinski \\ University of Strasbourg, France
}

\begin{abstract}
In the first chapter of Djihadisme: Le Retour du Sacrifice (Paris: Desclée de Brouwer, 2017), a new philosophical essay on the contemporary threat of jihadism, the author, Jacob Rogozinski, puts into question our current understanding and usages of the word "terrorism." The chapter argues that the concept of terrorism is often too vague and biased and that it should be replaced by a philosophical approach inspired by Michel Foucault's thoughts on power. Nonetheless, Foucault's work needs to be supplemented by the concept of "terror apparatus," and the author eventually aims to show how this concept can help for a better understanding of contemporary jihadism.
\end{abstract}

\section{Keywords}

Jihadism; Reign of Terror; terror apparatus; terrorism; witch hunts; Michel Foucault.

Strange is the fate of words. Not so long ago, nation-states would not deign to go to war against terrorists. That term designated an enemy, certainly, but a subordinate one. The fighting conducted against this enemy did not belong to the only war worthy of the name, that is, the war confronting regular armies representing States. The fight against terrorism did not involve the noble military profession; it was mainly the business of policemen and spies. In those days, a time nearly inseparable from the long history of mankind, wars were circumscribed in both space and duration. They started with a declaration of hostilities, saw military offenses and retreats, victories and defeats, and they ceased with an armistice followed or not by a peace treaty. The adversary one fought against, which was an identifiable and delimited enemy, was the target of a hostility limited to the duration of war: the enemy could have once been a friend or ally and could become one again in the future. In any case, it was possible to recognize it as an enemy, and this recognition was reciprocal. In the time of single combats and duels, it was possible to call the enemy by name and challenge him face-to-face. Even when the masses of combatants were mixed into an

\footnotetext{
1 Jacob Rogozinski, “D’efficaces et froides machines à tuer”, in Djihadisme : Le Retour du Sacrifice (Paris : Desclée de Brouwer, 2017), 27-45. Book chapter translated with Desclée de Brouwer's authorization.

This is an Open Access article distributed in accordance with the Creative Commons Attribution Non Commercial (CC-BY-NC-ND 4.0) license, which permits others to copy or share the article, provided original work is properly cited and that this is not done for commercial purposes. Users may not remix, transform, or build upon the material and may not distribute the modified material (bttp:// creativecommons.org/ licenses/by-nc/4.0/)
} 
indistinct crowd, the enemy was still recognizable by uniform or flags - this mutual recognition gave the fight to the death both its meaning and its limits.

It appears that those days have passed. Today, the terrorist is no longer the devious and despicable enemy who does not deserve to be fought in a war. On the contrary, he has become the major and ultimate figure of the Enemy, as if the only war worth fighting was, from now on, the "War on Terror." But are we still dealing with a war? Traditional military conflicts have given way to states of violence, forms of hostility more diffuse, and all the more relentless. There are no armies anymore, but rather clandestine networks, combatants without uniforms who no longer attack other combatants on battlefields, but strike civilians where they work or go out, in concert halls, or in café terraces. From now on, it is impossible to identify the starting or ending point of hostilities: everyone is now exposed to a constant threat which does not allow for any respite. It is impossible to locate this enemy who seems to have emerged from nowhere. It is impossible to effectively protect ourselves against an aggressor who usually does not originate in a foreign land, but in our own country; who was born and lived very close to us, our neighbour, our peer, our brother.

The temptation is great to identify the terrorist as he identifies us: as an absolute enemy, an evil entity calling for limitless hostility, calling for a total war which could only end once this enemy is annihilated. That is how Jihadists regard the enemy, the kafirs, the infidels, us. Hatred is increased by reciprocal hatred and may lead to imitating one's hated enemy. Western strategists have already fallen into this trap: they in turn regard terrorism as an absolute enemy, they wage a "War on Terror" that takes as its model the enemy, and only succeed in strengthening them. How can we break this vicious and fatal circle where terror and counter-terror sustain each other? How can we avoid giving in to hatred by demonizing an enemy who strikes us so savagely?

One must ask whether the theories and concepts that we use in relation to the jihadist phenomenon are adequate - especially the concept of "terrorism." Perhaps it is time to question this all-purpose notion. This is not an easy task, since the word itself carries a powerful emotional charge: simply pronouncing it is sufficient to bring up unbearable images of mutilated or burnt bodies... Terrorism is a word that, in itself, terrorizes, and the mute astonishment it causes tends to forbid any kind of reflection on what it means. For starters, let us point out an anomaly here: the suffix “-ism” generally refers to a political, philosophical, or religious doctrine whose followers openly declare their support. Yet, no movement ever defined itself as "terrorist." Even when some movements aim to terrorize their enemies (such as jihadists), they continue to name themselves differently, as combatants, partisans, a resistance, revolutionary militants, or "soldiers of the Caliphate." In short, the "terrorist" is always the other, the enemy that one fights. This pseudo-concept has a purely polemic function; it does not aim to explain, but only to denounce - but what is the value of a word so equivocal that it has been applied to Bin Laden as well as to Jean Moulin and Nelson Mandela?

Who has an interest in labelling opponents as "terrorists"? Those who, in a given territory, hold a monopoly on legitimate violence: States, which use this word to condemn nonstate movements challenging this monopoly. There are countless resistance movements fighting against a foreign occupation, or against repressive and totalitarian political regimes, 
who have been denounced as "terrorists" by the State they are resisting. By contrast, the word is almost never used to name the terror and persecutions those States can themselves exert. However, we know that these States never hesitated to terrorize the populations they wanted to dominate by practicing torture, public executions, deportations and collective massacres. Machiavelli laid out the theory for this in The Prince, and the politico-religious apparatus that was the Inquisition knew perfectly well how to use these techniques of domination. As stated in the Directorium Inquisitorum, an inquisitorial handbook published in Spain in the $16^{\text {th }}$ century: "It needs to be remembered that the main aim of the trial and condemnation to death is not to save the soul of the accused, but [...] to educate and terrify the people." Hence, the word "terrorism" is at the same time too vague and undifferentiated - it erases any distinction between different types of strategies and practices - but also too restrictive, since it does not apply to State terror.

A further difficulty can be added. In its common usage (that is, in law-enforcement or the media), the word seems to define an essential and permanent quality: an evil nature which would invariably produce identical effects. Yet, it occurs that movements accused of terrorism and responsible for numerous mass killings sometimes renounce their initial strategy, as did Yasser Arafat's Fatah, the IRA, the ETA, and the FARCs in Columbia. Their leaders sometimes accede to power and become respectable heads of state, as it happened in Algeria and in many other countries of the Third World. One may ask whether this static notion of terrorism can account for these changes in circumstances and strategies. For all these reasons, it seems to me that it is better not to use the word at all. And yet, one must find a way to name these murderous networks who commit attacks in order to terrorize their enemies. I propose defining them as terror apparatuses. It is not a matter of simply replacing one expression by another, but rather of thinking differently: to think in terms of strategies and apparatuses.

Foucault taught us to give up these allegedly universal categories, these essences with invariable attributes known as Madness, Reason, Man, or Power, in order to replace them with more subtle analyses that take into account apparatuses - that is to say, peculiar, flowing and heterogeneous assemblages articulating disparate elements - representations, practices, knowledge, institutions - and managing to capture subjects and subdue their bodies and souls. Produced each time by a historical context, faced with internal or external resistance, traversed by tensions, fracture lines, lines of flight, the apparatus continues to transform, extend, or restrict its scope, to modify its strategy and discourse, and sometimes to decompose itself to be recomposed in another form. The author of Discipline and Punish warned us about the misconception of locating power solely in the organization of the State. The power apparatuses that he describes are multifaceted networks that largely go beyond the scope of the central focus of power and branch out into the full depths of society, concentrating around numerous sites of micro-powers. It is therefore possible to conceive a terror apparatus as emerging from above, from a State strategy aiming to subject a population; or from below, from movements of resistance trying to fight against a regime, a State, or a foreign occupation.

How can such apparatuses be defined in a more precise way? Foucault distinguishes between apparatuses of exclusion (whose model is given by the Great Confinement of the 
mad in the Classical Age and of the lepers in the Middle Ages) and apparatuses of disciplinary normalization, such as the prison and the asylum, which replaced the former in the $19^{\text {th }}$ century. Strangely enough, he did not detect the existence of a very different kind of power apparatus, one which has neither the aim to exclude, nor to normalize or control, but only to annihilate its targets. It was these apparatuses that enabled the $16^{\text {th }}$ and $17^{\text {th }}$ century witch-hunts or, closer to our era, the extermination of Armenians, Jews, and Tutsis. One can define them as persecution apparatuses - provided that we understand this word in its original Latin meaning, where persequi means hunting down without respite, chasing until death. Persecutions can target isolated persons or narrow groups; when they expand to the point of targeting entire populations, I prefer to call them terror apparatuses; but they obey the same logic and are characterized by the same affect as persecution apparatuses (in the restricted sense of the term): hate is what primarily inspires them.

There is another aspect of apparatuses which Foucault did not sufficiently analyse: none of these apparatuses possesses an invariable nature and they are able to mutate in order to turn into apparatuses of a different type. It is quite possible that a terror apparatus can transform itself by privileging the peaceful conquest of State power. An apparatus of exclusion can also turn into an apparatus of terror and extermination. It is a little-known fact that the lepers of the Middle Ages, initially confined to the leprosarium, were then slaughtered during the $14^{\text {th }}$ century; and Jews in Europe have been several times confronted with the same dynamic which led them from ghettos to pyres or gas chambers. Other mutations are possible as well. Indeed, there are counter-apparatuses that, instead of reinforcing dominant apparatuses of power, aim, on the contrary, to resist them, to deepen their lines of fracture, to help the subdued subjects escape their hold. They may be identified as emancipatory apparatuses. They are inspired by the aspiration toward a more just world, by affects of uprising and hope. Yet, when these emancipated apparatuses succeed in seizing state power, they sometimes turn into apparatuses of state terror, as shown by the examples of the Jacobin Reign of Terror or by the $20^{\text {th }}$ century communist revolutions.

If we want to understand how a terror apparatus works, we must consider these mutations and analyse terror in a subtler and more differentiated way, for there are different kinds of terror which correspond to different kinds of apparatuses. First of all, we need to distinguish between what is a matter of violence and what is a matter of terror per se. When a furious crowd directs itself against a victim to lynch him, we are facing a spontaneous explosion of violence that can be rapidly restrained. On the contrary, a terror apparatus involves a deliberate strategy persisting over time. In this case, violence is intentionally used in order to produce certain effects, and its immediate victims do not necessarily coincide with its actual targets. It is an exemplary violence aimed at the people it wants to subdue, at occupying troops, or at the state that one seeks to intimidate, or "educate," through terror. It is, in other words, a strategic, instrumental violence which is not an end in itself but a means to another end. This kind of terror involves strategy and calculation. It therefore has a rational aspect and rarely oversteps certain limits. A great number of movements labelled "terrorist" actually belong to these strategic terror apparatuses, such as those fighting for their territory's independence. They most often abandon their strategy as soon as they reach their goals. This happens because they are not fundamentally inspired by hatred or by the 
desire to destroy their enemies to the very last. To the judges who asked Joan of Arc if, in her view, God hated the English, she superbly replied: "I do not know whether God likes or hates the English; I only know that we have to push them out of France."

By restricting the analysis to one type of apparatus, one risks misunderstanding what we call terrorism by only seeing it as a battle technique ("the weapon of the weak" ...) dictated by circumstances, and which can easily be abandoned. However, it happens that one terror strategy with limited objectives sometimes gives way to another kind of terror. Let us, for instance, consider the case of witch-hunts. Witch-hunts were most often directed against poor and elderly peasant women occupying a marginal place within their community. It happened many times, however, that persecution ran riot and struck cities as well as countryside, men as well as women, the rich as well as the poor, so that anyone could be accused and end up at the stake. In a very different context, one can identify an analogous phenomenon during the French Revolution: the relatively circumscribed terror decreed in autumn 1793 by the National Convention was followed a few months later by a limitless terror. The hunt for "suspects" was disproportionally expanded, while a true war of extermination was carried out in Vendée, where tens of thousands of civilians, including women and children, were slaughtered with the avowed aim of destroying a "race of rebels." Each time, one can notice the shift from a limited to an absolute hostility, from a strategic terror to a total terror whose target gets indefinitely enlarged. It is then no longer a matter of terrorizing a population by focused torture and assassinations to obtain its subjection: instead, the population in its entirety becomes the target.

It is difficult to comprehend what causes this deepening of the terror apparatus, and it is even more difficult to understand what could stop it. One thing is for sure, however: as organized and systematic as it might be, an apparatus of total terror is always inspired by hatred; for hatred is not just a savage and uncontrolled aggressiveness - it can be patient, calculating, and employ all the resources of human intelligence in order to destroy this absolute enemy that is chosen as a target. It happens that some even admit that they recognize that their actions are based on "a relentless hatred of the enemy, impelling us over and beyond the natural limitations that man is heir to, and transforming him into an effective, violent, selective and cold killing machine. Our soldiers must be thus; [a people without hatred cannot vanquish a brutal enemy]." It is about, the author adds, carrying "the war into every corner the enemy happens to carry it: to his home, to his centres of entertainment; a total war. It is necessary to prevent him from having a moment of peace, a quiet moment outside his barracks or even inside; we must attack him wherever he may be; make him feel like a cornered beast wherever he may move." This person praising total terror and hatred is not some fascist ideologue or an emir of Daesh. It is one of our past heroes, the icon of Third-World revolutions, Che Guevara...

These different types of terror and the different apparatuses that implement them are not always easy to distinguish. However, paying attention to the way they designate their enemies and delimit their targets could help us. Do they consider their adversary as a real enemy with whom it could be possible to reconcile, or as an absolute enemy, a "monster" unworthy of life? Do they solely target soldiers, policemen, heads of state, or do they also assassinate ordinary civilians? Do they only attack symbolic targets, or do they blindly 
slaughter to make the most possible victims? These criteria are significant, and yet none of them is absolutely relevant - for it is always possible that a terror apparatus gets carried away and that its delineations fade away. What about jihadist apparatuses? To which type or phase of terror do they correspond?

At first sight, it seems that we are confronted with a "defensive jihad," a strategy aiming to defend a delimited territory. Bin Laden created Al-Qaeda because he did not tolerate the presence of American military bases which, according to him, desecrated the holy land of Arabia. But let there be no mistake: if we were only dealing with a territorial strategy with limited objectives, we could envisage that jihadist organisations might one day come to renounce terror. However, we can be certain that this will not happen. Indeed, as soon as Al-Qaeda was founded, the organization defined its fundamental objective as the jibad against the "Far enemy," or as the "global jihad" that not only aims to push the infidels out of Muslim territories but also to "displace the fight on the enemy's territory," to "strike the enemy at its heart" through massive attacks. As Bin Laden's close friend Ayman al-Zawahiri wrote, it means "causing the most damage to the enemy, killing the most people, because this is the only language that the West understands." The 9/11 attacks or the attacks of November $13^{\text {th }}, 2015$ are the necessary consequences.

"Islam claims the whole earth, not a small part of it," stated Mawdudi, a fundamentalist thinker who is one of the jihadists' main references. The global nature of jihad means, indeed, that its aim is to establish the worldwide reign of Islam as they conceive it. This objective, as delirious as it might appear to us, is constitutive of their project. That is why the establishment of an "Islamic State" over parts of Iraq and Syria has never been envisaged by Daesh as an end in itself, but rather as a provisional step towards the foundation of an empire without borders whose ramifications have already begun to spread to Libya, Nigeria and Pakistan. The loss of Mosul and Raqqa is then only a provisional retreat which simply demands a change of strategy by prioritizing, again, the jihad against the "Far enemy." From this perspective, an attack striking New York or Paris no longer has the sole function of terrorizing the enemy. For the jihadist organization, it consists in marking its territory, a territory that is supposed to expand in an unlimited way. This enables it to affirm its global sovereignty, its absolute right to kill anywhere in the world.

We are told that the aim of those attacks would be to provoke hostile reactions of Westerners against Islam and, by repercussion, a massive enrollment in the jihad for Muslims in Western countries. This is not entirely false: this is what Daesh theorizes as the "destruction of the grey zone," the zone where Muslims naively imagine that they can coexist in a peaceful way with the Western "infidels." One can recognize here a classic strategy of escalation to extremes intended to make any kind of neutral position impossible and to strengthen the antagonism until the final victory. And yet, this strategical terror is not the ultima ratio of the jihadist project; for this project involves an absolute terror where the use of violence is no longer simply a means but becomes the final goal. As it is argued by the Pakistanis theorist of jihad, S.K. Malik, in his book The Quranic Concept of War: "Terror struck into the hearts of the enemies is not only a means, it is the end in itself. [...] It is the point where the means and the end meet and merge." 
This means that the distinction between a limited and strategic terror and total terror no longer makes sense in the case of jihadism. This is precisely the strategy it has chosen, that of the "global jihad" which leads to an absolute hostility, an unlimited extension of the target to be destroyed. "We will turn Europe into a cemetery," claimed Larossi Abballa, the murderer of the two policemen in Magnanville. Ultimately, the target extends to the populations of the entire planet, to those who would persist in resisting the conquering expansion of the new empire. This perspective is sketched in the manifesto of another jihad theorist. In the Management of Savagery, where Abu Bakr Naji introduces what would become Daesh's strategy, he commands "the burning of the homes and countries of the infidels." If they do not understand the lesson and do not convert to Islam, they will be "eradicated" and God will deliver "the earth and its human inhabitants from them."

We are not simply dealing with the delirium of a megalomaniac ideologue. The different facets of jihad terror manifested themselves in the most tangible way in the wave of attacks that spilled blood in France. The first attacks, indeed, were directed against specific targets, the soldiers murdered by Mohammed Merah, policemen, journalists accused of "blasphemy" and, as always, Jews. Those targeted killings would then be followed by attacks intended to produce as many victims as possible. One must not conclude from this that jihadists suddenly changed their strategy. In fact, similar attacks had already struck Madrid and London in 2004-2005. We must simply note that their terror apparatus can indifferently use those two methods of operation while maintaining the same fundamental objective, the same project of conquest and extermination. The strength and the truth of the phrase "Je suis Charlie" lies in this: it was not only about expressing solidarity with the victims, but also about stating that anyone could become a victim. Subsequent events have tragically confirmed this reality.

Translated by Jennifer Carter \& Ernesto Blanes

\section{References}

Foucault, Michel. Madness and Civilization. New York: Vintage Books, 1988. . The History of Sexuality. Volume I: An Introduction. New York, Vintage Books, 1990. . Discipline and Punish. New York: Vintage Books, 1995.

Machiavelli, Niccolo. The Prince. Cambridge: Cambridge University Press, 1988.

Rogozinski, Jacob. Ils m'ont haï sans raison. De la chasse aux sorcières à la Terreur. Paris: Éditions du Cerf, 2015. . Djihadisme: Le Retour du Sacrifice. Paris: Desclée de Brouwer, 2017. 